\title{
Violation of Maxim in Paranoid Schizophrenia Patients' Conversation
}

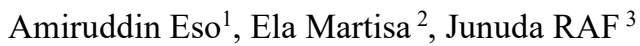 \\ \{amir_fk_unhalu@yahoo.co.id' ${ }^{1}$,ela.amiruddin@yahoo.com ${ }^{2}$,junudaraf2011@gmail.com ${ }^{3}$ \} \\ ${ }^{123}$ Department of Biomedical Science, ${ }^{123}$ Faculty of Medicine, Halu Oleo University Kendari, Sulawesi \\ Utara, Indonesia
}

\begin{abstract}
The present research is intended to find out the type of violation of maxim do by Paranoid Schizophrenia patients during their conversation and the causes of the violation. The method employed was descriptive qualitative approach and the data were obtained from six paranoid schizophrenia patients who were interviewed by co assistant doctor who in charge in mental hospital of South East Sulawesi. The utterances from the patients' conversation are recorded then analyzed and classified by using Grice theory. Then the result of violation is analyzed to find out the causes of the violation by using Scale for the Assessment of Thought, Language, and Communication (TLC) by Nancy Andreasen. The result of the research shows that patients indicate to violate three maxims proposed by Grice. The breakdowns are 6 utterances indicate the violation maxim of relation, 31 utterances indicate the violation maxim of quantity, and 10 utterances violate maxim of quality. The causes of violation are poverty of speech and tangentiality. It is concluded that the patients tend to shows form of disorganized speech production as well as adding exceed amount of information in their speech and also unreliable answer.
\end{abstract}

Keywords- Cooperative principle, paranoid schizophrenia, TLC, and violation maxim

\section{Introduction}

There is no doubt that language and brain has a close relationship. In communicating, the brain controls the process of producing language. There is a space in human brain particularly in left hemisphere that produces the language. [1] However, there are several conditions which show a disturbance in brain when producing the language. One of that condition is a disease called schizophrenia.

Schizophrenia, according to Schizophrenia Society of Canada / SSC [2] occur because of biochemical imbalance from neurotransmitter in the brain. This impairment can be seen in patients such delusion, hallucination, thought disorder and communication and avoid social interaction. The damage of brain started in the partial (region of brain) and spread to the rest of brain over a five years period. Schizophrenics have worst symptom, which include hallucinations, delusions, bizarre and psychotic thoughts, hearing voice and depression. They 
often show unusual language impairments. There are at least two kinds of impairment such as thought disorder (failure to maintain a discourse plan) and schizophasia (comprising various dysphasia-like impairments such as clanging, neologism, and unintelligible utterances). [3] That impairment causes the disruption communication between patients with schizophrenia and people around them.

There are seven types of schizophrenia. They are paranoid, hebephrenic, catatonic, unspecified and residual. In Mental Hospital of South East Sulawesi, Paranoid Schizophrenia is the most dominant subtypes that suffered by patients. Maslim (2013) state that at least, three criteria can be found in diagnosing of paranoid schizophrenia. First, patients have hallucinations that threaten them or give orders, or hallucinations without verbal form in the form of whistles, buzzing or laughter. Second, Smelling or smelling hallucinations, or sexual, or other bodily feelings, visual hallucinations may be present but are rarely prominent. Third, delusions can be of almost any type but delusions are controlled, influenced, or passivated, and beliefs being pursued in diverse ways are the most typical.[4]

As stated above, that patients with paranoid schizophrenia has thought disorder and communication and avoid social interaction. It leads them to have different ways in communicating. They have possibilities to violate the maxim in conversation. H.P. Grice, one of linguistic experts proposed a cooperative Principle as a certain restrictions on participants to adjust their speech in correspondence with the maxim. There are four maxims as concepts of the principle. First, The maxim of quality in which the speaker is expected to say the truth, to say what they feel which is correlated with the reality. Second, The maxim of quantity in which the speaker is expected to say something informative but not excessive. Third, The maxim of relation in which the speaker is expected to say something relevant from the previous speech. Last, The maxim of manner in which the speaker is expected to say something clearly and unambiguously. [5] In utter their speech, it will be categorized as violate the maxim when speaker do not follow the rules.

When schizophrenias' patient violates the maxim, it can be caused by several abnormality speech. There are several theories were proposed as causes of abnormality speech of schizophrenic such as Thought and Language Index (TLI) by liddle et.al and Scale for the Assessment of Thought, Language, and Communication ( TLC) by Nancy Andreasen. This paper used TLC to find out the causes of violation because it provides more items to be comprehended. There are 20 items of TLC. They are poverty of speech, poverty of content, pressure of speech, distractibility, tangentiality, derailment, circumstantiality, illogicality, incoherence, neologisms, word approximations, stilted speech, clanging, perseveration, echolalia, blocking, self- reference, loss of goal, paraphasia phonemic, and paraphasia semantic.[6]

There are several studies have been conducted related violation of maxim in conversation to the schizophrenic. The first study do by Agustina (2014). She analyzed the linguistic phenomena of schizophrenia suffered by Mary, the main character in Canvas movie. She tried to describe the language abnormalities and want to show and explain the accompanying behaviours acted by Mary. The findings show that five types of schizophrenic language abnormalities occur. They are perseveration of ideas, non-logical reasoning (peculiar logic), looseness, weakening of goal, and poverty of speech. Perseveration of ideas is the most-often appearing phenomenon made by a schizophrenic who always repeats the same word, phrase, and even sentence continuously. Besides, the other types have only small occurrences since they are not common abnormalities mainly found. Second, the deviant behaviours which are accompanied by a schizophrenic are also shown in the movie. The other deviant behaviours i.e. 
aggression, painting, affective flattening, and unnecessary use of water, have the most-often occurring phenomena in the schizophrenic. [7]

The second research do by Suryani (2015). This study focused on (1) schizophrenic speech deficits, (2) deficits of external deixis (ecofora) schizophrenic speech, (3) deficit of schizophrenic conversation structure, (4) deficits of schizophrenic speech relevance, and (5) therapeutic against the pragmatic deficit of schizophrenic speech (Yt) in Mental Hospital Menur Surabaya. The result indicated that (1) Yt experience imperfections in acts of speech representative, directive, expressive, commissive, and declarative; (2) Yt experiencing imperfections in referring to a matter related to space, persona, and time; (3) Yt experiencing imperfections in understanding the structure of the conversation in the form of turning, overlap, and adjacency pairs; (4) Yt experiencing imperfections of revealing speech; (5) therapeutic helps restore the thought disorder suffered by Yt. [8]

The third research do by Rahman (2017). She investigates the John Nash's utterances and conversation related to theory of Grice's maxim and also the causes of the violation. In this study, she found 28 conversation and 8 symptoms. that John Nash violates the maxim by talking too short, talking too much, doing circumlocution, lying, talking with strange slang, changing the topic abruptly, giving answer and respond unmatched with the topic, and avoiding talk something. The causes of violation are poverty of speech, poverty of content, pressure of speech, tangentiality, derailment, circumstantiality, stilted speech, and clanging. [9]

The four study was conducted by Jati et.al (2018). This research tries to classify the Grice maxim violation in six hebephrenic schizophrenia patients (three acute and three quiet phase) speech. The data are the transcribed and analyzed using the Cooperative Principles theory from Grice. It is found that the most frequently violated maxim is maxim of relation. Patients with hebephrenic schizophrenia in the acute phase do more violations than those in the quiet phase. From the total 70 violations of maxim of relation, 49 times occur in the utterances of patients in the acute phase and 21 times occur in those in the quiet phase. [10]

The last research was conducted by Nugroho (2018). He wrote a book about a schizophrenic, Toni Black, and investigate characteristic of Blacks' utterances. It founds that Black tends to violate all maxim in cooperative principle. It also found that he is still able to use cohesion device in speaking but lack in coherences. [11]

The present study is focused on finding out the violation of maxim do by six paranoid schizophrenia patients in Mental Hospital Kendari, South East Sulawesi. Their utterances are recorded, transcribed and analyzed by using cooperative principle by Grice. Then, the utterances also analyzed to find out the causes of violation by using TLC of Nancy Andreasen.

\section{Method}

In collecting the data, researchers were helped with the doctor who responsible with all the patients in mental hospital of South East Sulawesi. The doctor do interview with the patients and record the conversation. Then, the doctor gave the data in form of the transcription. Because of the large number of population in the mental hospital, then researchers only focus on patients with paranoid schizophrenia subtypes which are the biggest population in the hospital. 15 patients choosen as subjects of research purposively. However only six patients show give good responses in the conversation. The others are reluctant to speak and most doctor questions answered by their family who accompany them in the hospital. The interview was recorded then was transcribed. 
The transcription was analyzed and classifies to find out whether or not there is a violation of maxim. Grice cooperative principle was used as a basis theory. Then, the causes of violation are analyzed by used TLC theory proposed by Andreasen. Here, researchers read the transcription of interview and finding out the utterances which can be classified as the causes of violation based on TLC theory. After analyzing the maxim violation and the causes of violation, researchers conclude the result of the research.

\section{Result and Discussion}

From 6 patients utterances during the interview process it was found that the patients violated the principle of cooperation in communication. Three maxims were violated by the patients. The details of the violations of the maxim are 6 utterances indicate the violation maxim of relation, 31 utterances indicate the violation maxim of quantity, and 10 utterances violate maxim of quality. The causes of violation are poverty of speech and tangentiality.

Table 1 List of total amount of violation and causes of violation

\begin{tabular}{cccccc}
\hline No & Patient identity & \multicolumn{5}{c}{ Violation of maxim } \\
& & Quantity & Quality & Relation & Manner \\
\hline 1. & Mr. Und,25 years old & 6 & 4 & 3 & - \\
\hline 2 & Ms. Id, 36 years old & 2 & 1 & 2 & - \\
3 & Mr. Nrd & 9 & 3 & 1 & - \\
4 & Mrs. Ais & 7 & 2 & 1 & - \\
5 & Mr. Awd & 4 & 1 & 1 & - \\
6 & Mr. Hfd & 2 & 1 & - & - \\
\hline
\end{tabular}

Based on the result of research, it shows that all patients violate the maxim of quantity. From all subjects of research, the total utterances of the violation are 30 utterances. The main characteristic of this phenomena is the exceed information given by the patients in response the question from the doctor. Below are the one of excerpt of patient conversation. She is Mrs. Ais , a 45 years old house wife. (D : Doctor) and P : Patient

D: anaknya ada berapa sekarang bu? (How many children are there now, ma'am?)

P: anak saya tiga dok. Yang paling Kakak perempuan. Sekarang sudah menikah dan sudah punya mi 2 anak. Umur 23 tahun sekarang kayaknya. Yang kedua dan ketiga itu laki-laki. Anak ke dua sekarang lagi cari kerja di luar kota sejak lulus SMA. Sekarang umurnya 19 tahun. Anak yang bungsu inimi ( menunjuk anaknya yang masih kecil). Umurnya 7 tahun sudah seko lah juga. Yang kecil ini pintar Dok. Saya pikir-pikir mau kasih sekolah dokter. (My children are three, doc. The most sister. Now, she get married and already have 2 kids noodles. 23 years old now, I think. The second and third are men. The second child is now looking for work outside the city since graduating from high school. Now 19 years old. This is my youngest child (appoints a young child). 7 years old already school too. This little one is smart Doc. I thought about going to the doctor's school).

The conversation above is classified as violation of the maximum quantity. This is marked by giving an answer that exceeds the need for questions raised by $\mathrm{D}$. To not violate the maximum quantity, $\mathrm{P}$ should provide enough information about the numbers of her children. She does not need to explain too far about her children age, job, even idea. 
The second maxim that most violated is maxim of quality. The main characteristic of violation this maxim is the speaker is expected to say the truth, to say what they feel which is correlated with the reality. Here are the excerpt of the interview of Id, 26 years old girls.

D: Siapa yang mau bunuh kita?. ( Who are going to kill you?)

P: ...orang di sawah... yang pakai baju merah dan biru.

( Someone in the rice field... who wears red and blue $\mathrm{t}$ shirt.

The maxim of quality violation in the dialogue above is seen from the answer given by $\mathrm{P}$ to answer the question D. The context of the dialogue is $\mathrm{P}$ feel someone try to kill her. However her family believes it is only her hallucination because she is always at her room and seldom to interact with other member of family at home. Since she was categorized as a shizophrenic then her utterances consider as a lying eventhough she has no intention to lie. It is difficult to believe her speech under her condition. When compared between field facts and statements it indicates that $\mathrm{P}$ tries to make a fake imaging. Therefore, the above dialogue is included in the maxim of quality violation.

The other violation do by the patient is violation of maxim of relation. Below is the excerpt of the interview. He is Und, 25 years old.

D: Kalau begitu apa yang bapak rasakan sampai bapak di bawa ke RSJ ini? (then, what did you feel that they bring you in this mental hospital?)

P: begini Dok, keluarga saya tidak ada yang suka saya jadi polisi, mereka rencana mau pecat saya Dok, tapi saya ini tidak bisa di pecat. ( My family did not like me to be a policeman. They had a plan to fire me, but I can not to be fired)

In the conversation above, it appears that the patient is violating the maximum relation. For the types of questions above, the best answer that should be given by the patient is a statement that what he feel that bring him to the mental hospital. The best answer is telling the doctor about her healthy condition. However in answering the question, the patient gave irrelevant statement that how his family hate him and try to fire him. The patient's response indicated that he had violated the maxim of relation by providing answer which is not relevant to the question.

In the excerpt of conversation above, the cause of violation is poverty of content. Since the patient provide irrelevant answer to the question, the doctor did not get the point of reason of the patient being there. Although the patient reply the doctor question in long enough sentences but it convey little or no information.

The patient below has similar diagnose that violation of maxim of relation and causes of the violation is poverty of speech.

D: Siapa nama panggilan ta Kak? (who is youy nick name, sist?)

P....(diam).....Ida (dengan suara kecil). (...(silent)....Ida ( with low voice)

D:Dimana Alamat ta? (where are your address?)

P:...(diam)...(silent)

D:Apa keluhan ta' sampai di bawa kesini?. (What complaints do you get brought here?.)

P: ...(diam). (... (silent).

D: Apa yang kita rasa sekarang?. (What do you feel now?)

P: Saya tidak suka warna merah dan biru.( I don't like red and blue.)

In the interview above, the patient gives answers that do not connect with the type of question. $\mathrm{D}$ wants to dig up information about $\mathrm{P}$ in the form of what is felt. But $\mathrm{P}$ gives irrelevant answers.

The cause of the violation in the excerpt of conversation above is poverty of speech. The characteristic of this cause is there is a restriction in the amount of spontaneous speech. As a result, in replying a question, patient tends to be brief, concrete, and unelaborated. 


\section{Conclusion}

Three maxims which are violated by the patients are quantity, quality and relation. It indicates that there is a little differences with general characteristics of paranoid schizophrenia tend to shows form of disorganized speech production as well as adding exceed amount of information in their speech and also unreliable answer.

This indicates that the paranoid schizophrenia patients are still very influential on the speech which is produced by the schizophrenic patients at Mental Hospital of South East Sulawesi. It can be seen from the maxim of quantity and the quality of the most violated indicates that the patient's speech still meet the general characteristics of people with schizophrenia. For the causes of the violation are poverty of speech and tangentiality where patients tend to reply question in brief, concrete and unelaborated.

\section{References}

[1] Aitchison, J.: The Articulate Mammal: An Introduction to Phsycholinguistics $5^{\text {th }}$ edition. New York : Routledge. 2007

[2] Schizophrenia Society of Canada.: Learning About Schizophrenia: Rays of Hope A Refference Manual For Families \& Caregivers. Ed.3. Schizophrenia Society of Canada. Markham. 2003

[3] Titone, D. 2010. Language, communication, and schizophrenia. Journal of Neurolinguistics vol 23 issue 3, pages 173-175. 2010

[4] Maslim, R. Buku Saku Diagnosis Gangguan Jiwa Rujukan Ringkas dari PPDGJ-III dan DSM-5. Bagian Ilmu Kedokteran Jiwa FK-Unika Atmajaya, Jakarta. 2013.

[5] Grice, H. P. Logic and Conversation. New York: Oxford University Press. 1975

[6] Andreasen, Nancy. Scale for the Assessment of Thought, Language, and Comunication (TLC). Schizophrenia Buletin Vol 12. No.3. 1986

[7] Agustina, F. D. A psycholinguistic analysis of schizophrenic speech and behaviour portrayed in the main character In canvas movie. Yogyakarta State University. 2014

[8] Suryani, Y. Defisit Tindak Tutur Penderita Skizofrenia di RS Jiwa Menur Surabaya: Kajian Pragmatis Klinis. Jurnal Bahasa Indonesia, SAstra, dan Pengajarannya. Vol. 1 NO.2 Oktober 2015 http://journal.unesa.ac.id/index.php/jpi ISSN: 22477-5150. 2015

[9] Rahman, T. "The Violation of Grice's Conversational Maxims Performed by John Nash In 'A Beautiful Mind' Movie". English Department, Faculty of Art and Humanities. The State Islamic University of Sunan Ampel Surabaya. 2017

[10] Jati, D. A., Muslim, M. U., \& Aryani, U. Grice Maxim Violation in Schizophrenic Patients' Speech. Advances in Social Science, Education and Humanities Research (ASSEHR), 148(Icla 2017), 122-125. https://doi.org/10.2991/icla-17.2018.22. 2018

[11] Nugroho, W W. Karakteristik Bahasa Toni Blank: Kajian Psikolinguistik, Teori dan Praktek. Yogyakarta: UGM PRESS. 2018 